\title{
EDUKASI PENTINGNYA MENCUCI TANGAN DENGAN SABUN DI ERA NEW NORMAL
}

\author{
Melati Permata Hati ${ }^{11}$, Baiq Lenysia Puspita Anjani ${ }^{1}$, Nadya Silva Rosa1), Yuli Fitriani ${ }^{1}$, Dzun

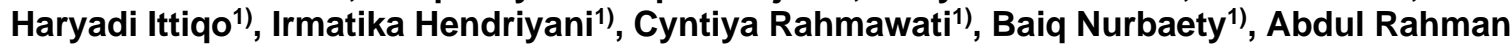 \\ Wahid ${ }^{1)}$, Nur Furqani1) \\ 1)Program Studi Diploma Farmasi, Fakultas Ilmu Kesehatan, Universitas Muhammadiyah Mataram, Mataram, NTB, \\ Indonesia \\ Corresponding author : Melati Permata Hati \\ E-mail : mela.hatipermata@gmail.com
}

Diterima 24 November 2021, Direvisi 19 Desember 2021, Disetujui 19 Desember 2021

\begin{abstract}
ABSTRAK
Tangan merupakan bagian tubuh yang paling sering bersentuhan dengan permukaan obyek di sekitar kegiatan manusia, yang tentunya akan sangat rentan sebagai pembawa kuman dan pathogen termasuk virus covid-19 yang saat ini menjadi musuh terbesar dunia. Untuk mendukung kegiatan sosial manusia, mencuci tangan dengan sabun merupakan salah satu langkah sanitasi yang dianjurkan di era new normal ini untuk mencegah penyebaran dan penularan covid-19. Sehingga, sabun cuci tangan dapat dikategorikan sebagai kebutuhan pokok. Bertepatan dengan memperingati "Hari Cuci Tangan Sedunia", maka kegiatan pengabdian ini meliputi edukasi untuk meningkatkan pemahaman dan kesadaran masyarakat mengenai pentingnya mencuci tangan dengan sabun dan langkah mencuci tangan dengan benar untuk mencegah penyakit dan hidup yang aman di era new normal
\end{abstract}

Kata kunci: sabun; mencuci tangan; new normal.

\begin{abstract}
Hands are part of body which touch hundreds of surfaces stuff a day which contain all kind of germs in the middle of our activities. But it might not realize just how much pathogens cause diseases especially COVID-19 that seriously case in the world. To support daily activities of society, washing hands is one of the best sanitation defences to against spread and infectious COVID-19 in this new era. So that, the important role played by hand hygiene is routinely washing hand with soap. To advocacy Global Handwashing Day in October 15, this program of activities for the community dedicated to increasing awareness and understanding about the importance of handwashing with soap as an effective and affordable way to prevent diseases and save live in new normal era.
\end{abstract}

Keywords: soap; washing hand; new normal.

\section{PENDAHULUAN}

Coronavirus disease (COVID-19) adalah penyakit infeksi pada saluran pernapasan yang disebabkan oleh virus SARCoV-2. Virus ini menyebar dengan mudah di seluruh dunia dengan cara kontak langsung maupun berinteraksi dengan jarak dekat. Sehingga dihimbau untuk menerapkan protocol Kesehatan. Sebagai makluk sosial, manusia tidak dapat menghindari sosial. Sehingga diterapkan hidup new normal yang berdamai dengan covid-19 tetapi harus tetap selalu menerapkan social distancing, menggunakan masker, dan mencuci tangan(Chaudhary et al., 2020).

Organisasi Kesehatan dunia (World Health Organization, United State Centers for Disease Prevention and Control, Chinese Center for Disease Control and Prevention, European Centre for Disease Prevention and
Control, dan lainnya) Sejak awal pandemic Covid-19 merekomendasikan pentingnya mencuci tangan dengan sabun dan air mengalir untuk mencegah penyebaran virus penyebab infeksi sindrom respiratori akut(Hygiene, 2009). Mencuci tangan dengan sabun secara rutin merupakan kegiatan utama sebagai kunci untuk mendapatkan tubuh yang sehat. Kebanyakan agen infeksius seperti virus saluran pernapasan dan enterik tersebar dari tangan yang terkontaminasi. Mencuci tangan dengan sabun dan air mengalir adalah rekomendasi yang utama untuk mencegah penyebaran virus, termasuk SARS-CoV-2 atau COVID-19(Rundle et al., 2020; Hadaway, 2020).

Selama pandemi ini, penyebaran segala bentuk pathogen, termasuk COVID-19 dapat terjadi dari orang yang terinfeksi ke orang yang tidak terinfeksi secara langsung melalui udara 
dalam bentuk droplet, melalui bersentuhan langsung dari benda sekitar yang telah disentuh atau melalui sentuhan tangan secara langsung. Mencuci tangan dengan sabun dan air terbukti efektif untuk membersihkan kotoran dan komponen organic (seperti mucus, sputum, dan komponen sekresi/ekskresi tubuh) yang dapat menempel di sekitar lingkungan hidup manusia. Patogen yang menempel di permukaan objek bersifat nonpolar (tidak larut dalam air). Sehingga jika membersihkan tangan hanya dengan air mengalir tidak dapat menghilangkan pathogen secara maksimal(IUPAC, 1997; ljaz et al., 2021; Grayson et al., 2009).

Sabun adalah komponen natrium atau kalium yang ada pada rantai Panjang asam lemak ( $\geq 8$ rantai karbon). Bentuk molekul ini disebut dengan surfaktan. Surfaktan adalah subtansi yang mampu menurunkan tegangan permukaan pathogen sehingga dapat diikat dan dibersihkan dari permukaan tangan dengan adanya air mengalir. Menurut penelitian, mencuci tangan dengan sabun secara komplit dapat menghilangkan virus setelah kontak 3060 detik. Berbeda dengan menggunakan hand sanitazer yang terbukti hanya merusak envelop (selubung) pathogen atau inaktivasi patogen oleh adanya kandungan alcohol yang tidak lebih dari 60\%(Mardiyani et al., 2020; Mona, 2020)

Pelaksanaan kegiatan pengabdian masyarakat ini dilaksanakan di Apotek Praya Farma, Lombik Tengah dengan secara langsung mendampingi masyarakat yang berkunjung ke apotek tersebut.. Karena global sudah menerapkan new normal, maka perlu adanya kebiasaan baru untuk dapat bertahan hidup dari pencegahan penyebaran COVID-19. Kegiatan ini mendukung "hari mencuci tangan se-dunia" setiap tanggal 15 Oktober dengan edukasi mencuci tangan dengan sabun dan air mengalir serta pembagian sabun cuci tangan.

\section{METODE}

Untuk dapat memaksimalkan hasil dari kegiatan ini, maka perlu adanya beberapa tahapan yaitu:

(1) Persiapan:

a. Penyusunan formula untuk pembuatan sabun. Formula disusun berdasarkan bahan-bahan yang mudah diperoleh.

b. Penentuan metode pembuatan sabun yang sederhana.

c. Persiapan pengadaan bahan untuk trial dan skala besar.

d. Pembuatan sabun dalam skala besar.

e. Pengamatan lokasi pelaksanaan di apotek mitra (Apotek Praya) termasuk kebiasaan masyarakat sekitar saat mengunjungi apotek, jumlah pengunjung, dan hari sibuk kunjungan.

(2) Pelaksanaan

Kegiatan ini dilaksanakan selama 1 (satu) hari yang dimulai dari tahap:

a. Pengarahan pengunjung untuk mencuci tangan sebelum memasuki area apotek

b. Memberikan sosialisasi mengenai pentingnya mencuci tangan dengan sabun dengan menunjukkan banner tahapan mencuci tangan dengan gerakan yang sederhana.

c. diskusi langsung oleh tim pengabdian masyarakat dengan pelanggan apotek Praya Farma

d. Pembagian sabun cuci tangan yang telah dibuat dengan kemasan botol pompa $50 \mathrm{~mL}$.

e. Praktek langsung cara mencuci tangan menggunakan sabun yang telah dibagikan di wastafel yang telah disediakan.

(3) Monitoring

Monitoring kegiatan sosialisasi dilakukan dengan mengamati cara mencuci tangan setiap pengunjung saat ingin meninggalkan lokasi apotek.

(4) Evaluasi

Evaluasi dilakukan dengan mengamati kesadaran masyarakat sebagai pelanggan yang rutin kontrol pengobatan dan terapinya di Apotek Praya Farma dalam mencuci tangan sesuai dengan arahan saat sosialisasi selama 1 (satu) minggu.

\section{HASIL DAN PEMBAHASAN}

Di era new normal dimana kehidupan bermasyarakat sekarang yang hidup di tengah penyebaran COVID-19 yang merupakan virus mematikan secara universal. Tentunya di era ini masyarakat dituntut untuk memaksimalkan kebiasaan baru untuk mencegah penularan COVID-19. Salah satu kebiasaan utama yang wajib diterapkan adalah mencuci tangan dengan sabun dan air mengalir. Sabun cuci tangan dibuat langsung oleh tim pengabdian masyarakat untuk dibagikan ke masyarakat secara gratis guna meningkatkan antusias masyarakat dalam mencoba langkah mencuci tangan yang kami jelaskan (gambar 1). Produk sabun cuci tangan kami beri nama Nucifera (gambar 2). 


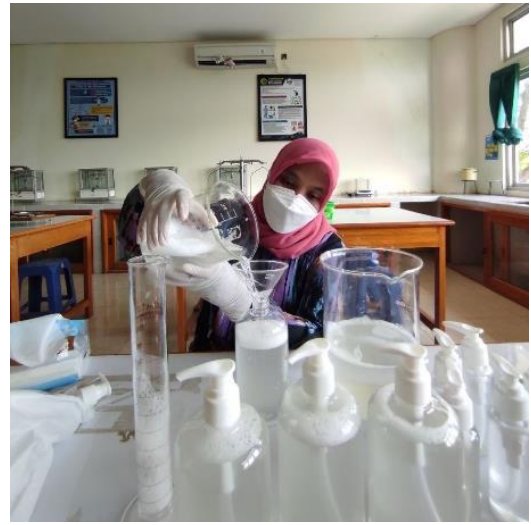

Gambar 1. Proses pembuatan sabun cuci tangan Nucifera

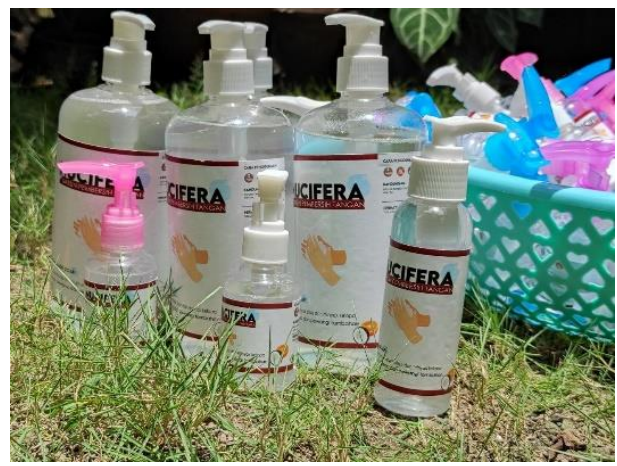

Gambar 2. Produk sabun cuci tangan Nucifera

Kebiasaan ini tentunya dapat dimaksimalkan dengan cara menerapkan tahapan mencuci tangan dengan benar agar terbebas dari pathogen secara maksimal selama beraktivitas. Masyarakat yang berkunjung ke apotek Praya Farma diberi edukasi dengan cara menjelaskan secara langsung dan mencantumkan ilustrasi langkah mencuci tangan dengan benar di banner kegiatan (gambar 3). Kegiatan ini kami lakukan selama 2 jam sebanyak 24 orang yang berkunjung secara bergantian di apotek Praya Farma.

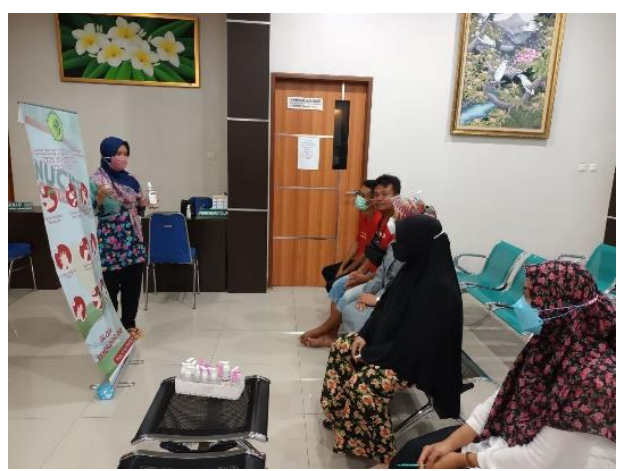

Gambar 3. Tim pengabdian masyarakat menjelaskan tentang pentingnya mencuci tangan dengan sabun.

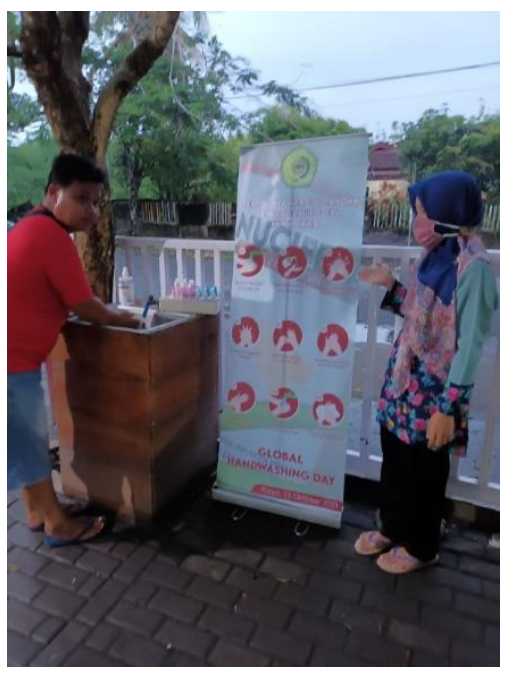

Gambar 4. Masyarakat mengaplikasikan langsung cara mencuci tangan yang benar di wastafel

Hasil dari diskusi penjelasan ini disambut baik oleh masyarakat. Masyarkat mengaku baru menyadari bahwa hal sepele seperti mencuci tangan dengan sabun dapat berdampak besar bagi Kesehatan. Tentunya dengan langkah mencuci tangan yang sederhana hanya dengan 6 langkah maksimal 1 menit tidak akan menyulitkan aktivitas masyarakat. Edukasi yang diberikan langsung dipraktekan oleh masyarakat di wastafel yang telah tim sediakan sebelum meninggalkan apotek Praya Farma (gambar 4). Masyarakat dapat dengan mudah mengingat langkah mencuci tangan yang kami jelaskan dan banner tersebut kami pasang di samping wastafel agar mudah diikuti oleh pengunjung.

\section{SIMPULAN DAN SARAN}

Kegiatan ini berhasil menambah pengetahuan masyarakat tentang pentingnya mencuci tangan dengan sabun dan air mengalir dan dengan mudah dapat menerapkan langkah cara mencuci tangan yang benar untuk memaksimalkan pembersihan tangan dari berbagai bentuk pathogen. Masyarakat menyambut dan mendukung dengan sangat baik dengan mengajak dan saling mengajari rekan-rekan terdekatnya.

\section{DAFTAR RUJUKAN}

Chaudhary, N. K., Chaudhary, N., Dahal, M., Guragain, B., Rai, S., Chaudhary, R., Sachin, K., Lamichhane-Khadka, R., \& Bhattarai, A. (2020). Fighting the SARS CoV-2 (COVID-19) pandemic with soap. Preprints, 60, 1-19.

Grayson, M. L., Melvani, S., Druce, J., Barr, I. G., Ballard, S. A., Johnson, P. D. R., Mastorakos, T., \& Birch, C. (2009). Efficacy of soap and water and alcohol- 
based hand-rub preparations against live H1N1 influenza virus on the hands of human volunteers. Clinical Infectious Diseases, 48(3), 285-291.

Hadaway, A. (2020). Handwashing: clean hands save lives. Journal of Consumer Health on the Internet, 24(1), 43-49.

Hygiene, W. H. O. H. (2009). WHO guidelines on hand hygiene in health care. WHO, Geneva.

ljaz, M. K., Nims, R. W., de Szalay, S., \& Rubino, J. R. (2021). Soap, water, and severe acute respiratory syndrome coronavirus 2 (SARS-CoV-2): an ancient handwashing strategy for preventing dissemination of a novel virus. PeerJ, 9, e12041.

IUPAC, I. (1997). Compendium of chemical terminology. In the "Gold Book." Blackwell Scientific Publications Oxford.

Mardiyani, S. A., Hidayatullah, M., Sofa, M. Z., Delphia, P., Muhamad, H., Nugraha, M. A. T., Pirain, A. S., Yaqin, M. A., Bajuber, H. A. A., \& Mulya, M. B. B. (2020). Edukasi Praktek Cuci Tangan Standar WHO dan Peduli Lingkungan. Jurnal Pembelajaran Pemberdayaan Masyarakat (JP2M), 1(2), 85-91.

Mona, N. (2020). Konsep isolasi dalam jaringan sosial untuk meminimalisasi efek contagious (kasus penyebaran virus corona di Indonesia). Jurnal Sosial Humaniora Terapan, 2(2).

Rundle, C. W., Presley, C. L., Militello, M., Barber, C., Powell, D. L., Jacob, S. E., Atwater, A. R., Watsky, K. L., Yu, J., \& Dunnick, C. A. (2020). Hand hygiene during COVID-19: recommendations from the American Contact Dermatitis Society. Journal of the American Academy of Dermatology.

United States Centers for Disease Control and Prevention. (2020). Q\&A for consumers: hand sanitizers and COVID-19. Food and Drug Administration. 